\title{
Deep oceanographic changes in the South Tyrrhenian Sea during the time of last Mediterranean Sapropel formation
}

\author{
S. Trias-NAVARRO ${ }^{1,2}$, I. CACHO ${ }^{1}$, L.D. PENA ${ }^{1}$, M. DE LA \\ FuENTE $^{1}$, A. CATAl ${ }^{1}$, J. FRIGOLA ${ }^{1}$, E. PAREdes ${ }^{1}$, E. \\ GARCIA-SOLSONA ${ }^{1}$, F. LIRER ${ }^{3}$ AND A. CARUSO ${ }^{2}$ \\ ${ }^{1}$ Departament de Dinàmica de la Terra i de l'Oceà, Facultat de \\ Ciències de la Terra, Universitat. de Barcelona, C/Martí i \\ Franquès s/n, 08028 Barcelona, Spain. \\ ${ }^{2}$ Dipartimento di Scienze della Terra e del Mare, Università degli \\ studi di Palermo, via Archirafi 20-22, 90123 Palermo, Italy. \\ ${ }^{3}$ Istituto di Scienze Marine-CNR, Sede Napoli, Calata Porta di \\ Massa, Interno Porto di Napoli, 80133, Napoli, Italy.
}

The Mediterranean Sea is a semi-enclosed sea formed by two different basins connected through the Strait of Sicily. Four main convection cells interconnected to each other fuel the Mediterranean Thermohaline Circulation (Med-THC), but their behaviour during past climate changes is not fully understood. The present study focuses on the analysis of the sediment core NDT-62016 from the South Tyrrhenian basin, which covers the last 14 kyr cal. BP, and therefore allows two key events in the Med-THC to be explored: the last organic rich layer (ORL) and the last sapropel (S1), that took place diachronically in the $\mathrm{W}$ and $\mathrm{E}$ Medbasins, respectively. NDT-6-2016 was recovered at $1066 \mathrm{~m}$ water depth, which is at present-day the depth of the interphase layer between the E- and W-originated Mediterranean water masses in the region. Therefore, it is suitable to evaluate changes in the water masses properties transferred from the $\mathrm{E}$ to the $\mathrm{W}$ Medbasins.

Changes in deep-water properties are reconstructed using a wide array of geochemical and sedimentological proxies. Elemental analyses in bulk sediment, as well as U/Mn measurements in planktonic foraminifera coatings, suggest the dominance of stable well-oxygenated conditions over the last 14 kyr cal. BP with some minor oscillations. However, $\delta^{18} \mathrm{O}$ and $\mathrm{Mg} / \mathrm{Ca}$ analyses in benthic foraminifera reveal significant changes in the physical properties of the deep waters, such as temperature and salinity, in agreement with the formation phases of the ORL and the S1 which are consistent with variations in the intensity of deep-water currents suggested by grain-size analyses. $\mathrm{Nd}$ isotopes measured in planktonic foraminifera coatings suggest that the observed oceanographic changes might be related to oscillations in the export rates of E-Med sourced water masses into the South Tyrrhenian Sea. 